\title{
Responses of Ventilatory Functions to Breathing Exercise versus Breathing Exercise with Chest Mobilizing Exercise in Elderly
}

\author{
Mohamed Ibrahim, Uomna Kamel Mohamed* and Atta Akram Ibrahim \\ Faculty of Physiotherapy, October $6^{\text {th }}$ University \\ *Faculty of Medicine, October $6^{\text {th }}$ University
}

\begin{abstract}
Ageing is a complex process involving many variables (e.g. genetics, lifestyle factors, chronic diseases) that interact with one another, greatly influencing the manner in which we age. The lungs of elderly persons are subjected to a life time of exposure to known and unknown harmful agents. The aim of this study was to investigate the responses of ventilatory functions to breathing exercise versus breathing exercise with chest mobilizing exercise in elderly. In this study, 30 elderly subjects were clinically examined \& subjected to laboratory investigations, and then randomly divided into 2groups ( $A$ \& B), where group " $A$ " received diaphragmatic breathing exercise \& incentive spirometer while group " $B$ " received diaphragmatic breathing exercise, incentive spirometer \& chest mobilizing exercise. The variables related to ventilatory functions Forced Vital Capacity (FVC), Forced Expiratory Volume at the $1^{\text {st }}$ second $\left(F E V_{1}\right)$ \& Maximum voluntary ventilation (MVV) had been measured twice; $1^{\text {st }}$ at the beginning of the program (pre-exercise) $\& 2^{\text {nd }}$ after 8 weeks (postexercise). The results showed that the ventilatory functions reported statistical significant $(p<0.0001)$ improvement at post-exercise within each group when compared with pre-exercise mean values.
\end{abstract}

\section{INTRODUCTION}

The process of ageing and senescence is associated with a decline in several organ functions, ultimately takes away independence and reduces quality of life. The impaired functional reserves of the immune, pulmonary \& cardiovascular systems are considered the most important causes of increased hospitalization in the older population. ${ }^{(1)}$

As ageing occurs, the respiratory system undergoes a measurable decline in its physiological function including thoracic cage stiffness which can be attributed to calcification of the costal cartilages and articulations between the vertebrae and ribs which results in increased kyphosis with increased work demand of the respiratory muscles and so increased breathing, while decrease in $\mathrm{FEV}_{1}, \mathrm{FVC} \& \mathrm{VC}$ and increased $\mathrm{RV} \&$ increase in FRC. (2)

Spirometric studies may be served as useful indicator for the purpose of anticipating and preventing complications of pulmonary impairment. $^{(3)}$ 
Breathing exercises are used to improve respiratory muscle function, exercise performance $\&$ health related quality of life in aged patient. ${ }^{(4)}$

Chest mobilization exercises are any exercises that combine active movements of the trunk or extremities with deep breathing. ${ }^{(5)}$

Improvement in FVC is due to increasing the strength of respiratory muscles and decreasing the air way resistance. $^{(6)}$

Inspiratory muscle training will improve ventilatory limitation for patients with COPD of $\geq 80$ years old. ${ }^{(7)}$

\section{SUBJECTS, MATERIALS \& METHODS}

\section{Subjects:}

30 elderly subjects of both sexes, their average age was between $65-80$ years old, their average body weight according to BMI ranges between $22.1-24.9 \mathrm{~kg} / \mathrm{m}^{2}$, all of them were clinically examined for chest diseases (e.g. Pulmonary embolism), cardiovascular diseases (e.g. Heart failure) and neurological diseases, in addition, all of them were subjected to laboratory investigations (i.e. CBC, sGOT, sGPT, sCreatinine, FBS, PPBS, sCholesterol "Total, HDL \& LDL" and Triglycerides) and they were also subjected to ECG \& Echo Cardio Gram) to be sure that they were free from any medical problems (that may interfere with their performance),non smokers \& mentally alert.

Materials:

a) For evaluation:

1-"Weight and height scale" to calculate the BMI, as:

$\mathrm{BMI}=$ weight $(\mathrm{Kg}) /$ height $\left(\mathrm{m}^{2}\right)$.
2-"Discovery hand held computerized spirometer" to measure FVC, FEV1 \& MVV before \& after performing the procedures of the study.

b) For treatment:

1-"Incentive spirometer (IS)", Triflow II type RESPI PROGRAM.

2-"Stop watch" to calculate the time of exercise.

\section{Methods:}

a) Evaluation procedures:

Subjects were medically examined and data were collected and recorded in sheets for each subject (i.e. name, age, weight $\&$ height).

Computerized spirometer was used for each subject to record the initial $\mathrm{FVC}, \mathrm{FEV}_{1} \& \mathrm{MVV}$.

I- Procedures to measure FVC:

1.Let the subject to be in a sitting position.

2.The subject was told to close his lips firmly around the new mouth piece that was given to him.

3.Pressing the "FVC push" button.

4.The subject was asked to fill his lungs with air slowly \& completely, and then exhale it as quickly \& completely as possible through the mouth piece.

N.B. Let the subject use a nasal clip to make sure that there is no air escapes from the nose.

II- Procedures to measure FEV $V_{1}$ :

1. Follow the same steps in $1 \& 2$ (as FVC).

2.Pressing "FEV 1 push" button.

3. The subject was asked to take normal quite breath, and then blow it hard \&fast as much as possible through the mouth piece.

N.B. This was repeated for 3 times \& then the average was taken.

III- Procedures to measure MVV: 
1.Follow the same steps in $1 \& 2$ (as FVC).

2.Pressing "MVV push" button.

3. The subject was asked to inhale \& exhale as quickly as possible (as the person would hyperventilate for $12 \mathrm{sec}$ ).

N.B. The test was done in a well lightened \& properly ventilated room (i.e. without air drafts).

\section{b) Therapeutic procedures:}

The participants were randomly assigned into 2 equal groups:

\section{Group (A):}

15 elderly subjects who received the breathing exercises program which consisted of:

1) Diaphragmatic breathing exercise (15 min):

- The subject was sat in a long sitting position in bed with head \& trunk supported comfortably \& elevated about $45^{\circ}$; both knees were slightly flexed \& supported by pillow \& the abdominal muscles remained relaxed.

- The therapist's hand was put on the upper part of rectus abdominis.

- The subject was asked to breathe in through his nose slowly \& deeply while keeping his shoulders relaxed and the upper chest quiet \& allowing his abdomen to rise.

- The subject was instructed to get all the air out from his mouth as much as possible.

N.B. That was done 3 times then rest for $30 \mathrm{sec}$ and was repeated for 15 $\mathrm{min} / \mathrm{session}$.

2) Incentive spirometer (15 $\mathrm{min})$ :

- The subject was placed in a comfortable position.

- The subject was asked to hold the spirometery by one hand and the tube of mouthpiece by the other hand.
- He was asked to take 3-4 slow easy breaths.

- He was asked to maximally exhale with the 4th breath.

- The subject was asked to place the incentive spirometer in his mouth and maximally inhale through the spirometery and hold the inspiration for several sec and then rest for $60 \mathrm{sec}$.

N.B. That was repeated for $15 \mathrm{~min}$.

Group (B):

15 elderly subjects who received the breathing exercises program which consisted of:

1) Diaphragmatic breathing exercise (10 min).

2) Incentive spirometer (10 $\mathrm{min})$.

3) Chest mobilizing exercise (10 $\mathrm{min})$ :

-- To mobilize the upper chest \& stretch the pictoralis muscles:

- The subject was asked to sit on an armed chair with his hands clasped behind his head.

- Then he abducted his arms during inspiration.

- Then he brought his elbows together \& then bent them forward during expiration.

N.B. That was repeated 3-4 times then rest for $60 \mathrm{sec}$.

-- To increase expiration during deep breathing:

- The subject was asked to breath in while he was sitting in a "hooked lying position" (i.e. hips \& knees are slightly flexed).

- He was instructed to pull both knees to the chest (one at a time to protect his low back) during expiration.

- That pushed the abdominal contents superiorly into the diaphragm to assist with expiration.

N.B. That was repeated 3-4 times. The whole program was performed for each group 3times/week for 8 weeks. 


\section{RESULTS}

Table (1): Demographic characteristics of both groups:

\begin{tabular}{|c|c|c|c|c|}
\hline \multirow{2}{*}{ Variables } & \multicolumn{2}{|c|}{ Age (years) } & \multicolumn{2}{c|}{ BMI $\left(\mathrm{Kg} / \mathrm{m}^{2}\right)$} \\
\cline { 2 - 5 } & Gr (A) & Gr (B) & Gr (A) & Gr (B) \\
\hline $\mathbf{X}$ & 73.47 & 73.40 & 23.55 & 23.43 \\
\hline SD \pm & $4.91 \pm$ & $5.12 \pm$ & $1.11 \pm$ & $0.97 \pm$ \\
\hline MD & \multicolumn{2}{|c|}{0.07} & \multicolumn{2}{c|}{0.13} \\
\hline T - value & \multicolumn{2}{|c|}{0.047} & \multicolumn{2}{c|}{0.334} \\
\hline P - value & \multicolumn{2}{|c|}{$0.963(\mathrm{P}>0.05)$} & \multicolumn{2}{c|}{$\mathrm{NS}$} \\
\hline Significance & \multicolumn{2}{|c}{ NS } & \multicolumn{2}{c|}{} \\
\hline
\end{tabular}

Table (2): Comparison between the mean values of ventilatory functions at pre $\&$ post exercises for each group (A \& B):

\begin{tabular}{|c|c|c|c|c|c|c|c|c|}
\hline \multirow{2}{*}{\multicolumn{3}{|c|}{ Ventilatory functions }} & \multicolumn{6}{|c|}{ Variables } \\
\hline & & & \multirow{3}{*}{$\begin{array}{c}\mathbf{X} \pm \mathbf{S D} \\
1.105 \\
\pm 0.077 \\
1.350 \\
\pm 0.107\end{array}$} & \multirow{3}{*}{$\begin{array}{c}\text { MD } \\
-0.245\end{array}$} & \multirow{3}{*}{$\begin{array}{c}\text { T-value } \\
6.216\end{array}$} & \multirow{5}{*}{$\begin{array}{c}\text { P-value } \\
\\
0.0001 \\
(\mathrm{P}<0.05)\end{array}$} & \multirow{5}{*}{$\begin{array}{c}\text { Sign. } \\
\\
\text { S }\end{array}$} & \multirow{3}{*}{$\begin{array}{c}\begin{array}{c}\% \text { of } \\
\text { changes }\end{array} \\
22.20 \%\end{array}$} \\
\hline \multirow{4}{*}{$\begin{array}{c}\text { FVC } \\
\text { (Liters) }\end{array}$} & \multirow{2}{*}{ Gr. A } & $\begin{array}{c}\text { Pre- } \\
\text { exercise }\end{array}$ & & & & & & \\
\hline & & $\begin{array}{c}\text { Post- } \\
\text { exercise }\end{array}$ & & & & & & \\
\hline & \multirow{2}{*}{ Gr. B } & $\begin{array}{c}\text { Pre- } \\
\text { exercise }\end{array}$ & $\begin{array}{c}1.103 \\
\pm 0.077\end{array}$ & \multirow{2}{*}{-0.365} & \multirow{2}{*}{12.192} & & & \\
\hline & & $\begin{array}{c}\text { Post- } \\
\text { exercise }\end{array}$ & $\begin{array}{c}1.469 \\
\pm 0.074\end{array}$ & & & & & $33.12 \%$ \\
\hline \multirow{4}{*}{$\begin{array}{c}\mathbf{F E V}_{1} \\
\text { (Liters) }\end{array}$} & \multirow{2}{*}{ Gr. A } & $\begin{array}{c}\text { Pre- } \\
\text { exercise }\end{array}$ & $\begin{array}{c}1.390 \\
\pm 0.213\end{array}$ & \multirow{2}{*}{-0.223} & \multirow{2}{*}{7.275} & \multirow{4}{*}{$\begin{array}{c}0.0001 \\
(\mathrm{P}<0.05)\end{array}$} & \multirow{4}{*}{$\mathrm{S}$} & $16060 /$ \\
\hline & & $\begin{array}{c}\text { Post- } \\
\text { exercise }\end{array}$ & $\begin{array}{c}1.613 \\
\pm 0.166\end{array}$ & & & & & $10.06 \%$ \\
\hline & \multirow{2}{*}{ Gr. B } & $\begin{array}{c}\text { Pre- } \\
\text { exercise }\end{array}$ & $\begin{array}{c}1.357 \\
\pm 0.222\end{array}$ & \multirow{2}{*}{-0.289} & \multirow{2}{*}{6.093} & & & 21270 \\
\hline & & $\begin{array}{c}\text { Post- } \\
\text { exercise }\end{array}$ & $\begin{array}{c}1.646 \\
\pm 0.122\end{array}$ & & & & & $21.21 \%$ \\
\hline \multirow{4}{*}{$\begin{array}{c}\text { MVV } \\
\text { (Liters/ } \\
\text { min) }\end{array}$} & \multirow{2}{*}{ Gr. A } & $\begin{array}{c}\text { Pre- } \\
\text { exercise }\end{array}$ & $\begin{array}{l}43.410 \\
\pm 1.383 \\
\end{array}$ & \multirow{2}{*}{-6.554} & \multirow{2}{*}{11.447} & \multirow{4}{*}{$\begin{array}{c}0.0001 \\
(\mathrm{P}<0.05)\end{array}$} & \multirow{4}{*}{ S } & $1510 \%$ \\
\hline & & $\begin{array}{c}\text { Post- } \\
\text { exercise }\end{array}$ & $\begin{array}{l}49.964 \\
\pm 3.114\end{array}$ & & & & & $15.10 \%$ \\
\hline & \multirow{2}{*}{ Gr. B } & $\begin{array}{c}\text { Pre- } \\
\text { exercise }\end{array}$ & $\begin{array}{l}43.967 \\
\pm 1.350\end{array}$ & \multirow{2}{*}{-10.509} & \multirow{2}{*}{8.410} & & & $300 \%$ \\
\hline & & $\begin{array}{c}\text { Post- } \\
\text { exercise }\end{array}$ & $\begin{array}{l}54.475 \\
\pm 5.394\end{array}$ & & & & & $25.90 \%$ \\
\hline
\end{tabular}


Table (3): Comparative analysis of the mean values of ventilatory functions between both groups (A \& B) at pre \& post exercises:

\begin{tabular}{|c|c|c|c|c|c|c|c|}
\hline \multirow{2}{*}{\multicolumn{3}{|c|}{ Ventilatory functions }} & \multicolumn{5}{|c|}{ Variables } \\
\hline & & & $\mathbf{X} \pm \mathrm{SD}$ & MD & T-value & P-value & Sign. \\
\hline \multirow{4}{*}{$\begin{array}{c}\text { FVC } \\
\text { (Liters) }\end{array}$} & \multirow{2}{*}{$\begin{array}{c}\text { Pre- } \\
\text { exercise }\end{array}$} & Gr. A & $\begin{array}{c}1.105 \\
\pm 0.077\end{array}$ & \multirow{2}{*}{0.002} & \multirow{2}{*}{0.071} & \multirow{2}{*}{$\begin{array}{c}0.94 \\
(p>0.05)\end{array}$} & \multirow{2}{*}{ NS } \\
\hline & & Gr. B & $\begin{array}{c}1.103 \\
\pm 0.077\end{array}$ & & & & \\
\hline & \multirow{2}{*}{$\begin{array}{c}\text { Post- } \\
\text { exercise }\end{array}$} & Gr. A & $\begin{array}{c}1.363 \\
\pm 0.099\end{array}$ & \multirow{2}{*}{-0.106} & \multirow{2}{*}{3.333} & \multirow{2}{*}{$\begin{array}{c}0.002 \\
(p<0.05)\end{array}$} & \multirow[b]{2}{*}{$\mathrm{S}$} \\
\hline & & Gr. B & $\begin{array}{c}1.469 \\
\pm 0.074\end{array}$ & & & & \\
\hline \multirow{4}{*}{$\begin{array}{c}\mathbf{F E V}_{1} \\
\text { (Liters) }\end{array}$} & \multirow{2}{*}{$\begin{array}{c}\text { Pre- } \\
\text { exercise }\end{array}$} & Gr. A & $\begin{array}{c}1.390 \\
\pm 0.213 \\
\end{array}$ & \multirow{2}{*}{0.033} & \multirow{2}{*}{0.411} & \multirow{2}{*}{$\begin{array}{c}0.68 \\
(\mathrm{P}>0.05)\end{array}$} & \multirow{2}{*}{ NS } \\
\hline & & Gr. B & $\begin{array}{c}1.357 \\
\pm 0.222\end{array}$ & & & & \\
\hline & \multirow{2}{*}{$\begin{array}{c}\text { Post- } \\
\text { exercise }\end{array}$} & Gr. A & $\begin{array}{c}1.613 \\
\pm 0.166\end{array}$ & \multirow{2}{*}{-0.033} & \multirow{2}{*}{0.684} & \multirow{2}{*}{$\begin{array}{c}0.54 \\
(\mathrm{P}>0.05)\end{array}$} & \multirow{2}{*}{ NS } \\
\hline & & Gr. B & $\begin{array}{c}1.646 \\
\pm 0.122\end{array}$ & & & & \\
\hline \multirow{4}{*}{$\begin{array}{l}\text { MVV } \\
\text { (Liters/ } \\
\text { min) }\end{array}$} & \multirow{2}{*}{$\begin{array}{c}\text { Pre- } \\
\text { exercise }\end{array}$} & Gr. A & $\begin{array}{l}43.410 \\
\pm 1.383\end{array}$ & \multirow{2}{*}{-0.557} & \multirow{2}{*}{1.116} & \multirow{2}{*}{$\begin{array}{c}0.27 \\
(\mathrm{P}>0.05)\end{array}$} & \multirow{2}{*}{ NS } \\
\hline & & Gr. B & $\begin{array}{l}43.967 \\
\pm 1.350 \\
\end{array}$ & & & & \\
\hline & \multirow{2}{*}{$\begin{array}{c}\text { Post- } \\
\text { exercise }\end{array}$} & Gr. A & $\begin{array}{r}49.964 \\
\pm 3.114 \\
\end{array}$ & \multirow{2}{*}{-4.505} & \multirow{2}{*}{2.799} & \multirow{2}{*}{$\begin{array}{c}0.009 \\
(\mathrm{P}<0.05)\end{array}$} & \multirow{2}{*}{$\mathrm{S}$} \\
\hline & & Gr. B & $\begin{array}{l}54.469 \\
\pm 5.399 \\
\end{array}$ & & & & \\
\hline
\end{tabular}

$\mathrm{X}=$ Mean

$\mathrm{SD}=$ Standard deviation

$\mathrm{MD}=$ Mean difference

$\mathrm{T}$ value $=$ Paired $\mathrm{T}$ value

$P$ value $=$ Probability value

Min $=$ Minute

Sign.$=$ Significance

$\mathrm{S}=$ Significant

NS $=$ Non Significant

Gr. $=$ Group 


\section{DISCUSSION}

The evaluation of ventilatory functions was made with Futuremed Discovery Spirometer which allows easy, sensitive and rapid calculation of FVC, $\mathrm{FEV}_{1}$ \& MVV. These measurements were recorded for each subject at both groups twice, $1^{\text {st }}$ one was before the program \& the $2^{\text {nd }}$ one was at the end of the $8^{\text {th }}$ week.

Aaron et al., 1999 used spirometer to analyze ventilatory functions in pulmonary impairment conditions. $^{(8)}$

Considering to previous concepts Balatopoulos et al., 2000 used spirometry to detect $\mathrm{FVC}, \mathrm{FEV}_{1}$ \& MVV for elderly. ${ }^{(9)}$

According to Youn et al., 2001 that used spirometry as the main technique currently used to detect altered ventilatory functions in elderly. ${ }^{(10)}$

Ali, H. et al., 2007 used spirometry to detect $\mathrm{FVC} \& \mathrm{FEV}_{1}$ for 30 moderate asthmatic patients. Also, El-Sayed et al., 2007 used spirometry to study the relation of ventilatory function to different classes of obese women. ${ }^{(11)}$

All participants were assigned into 2 equal studied groups: "group A" had performed diaphragmatic breathing exercise and incentive spirometer exercise, while "group B" had performed diaphragmatic breathing exercise, incentive spirometer exercise and chest mobilizing exercise.

The present study demonstrated that elderly subject tends to make a significant decrease in $\mathrm{FVC}, \mathrm{FEV}_{1}$ \& MVV after the age of 65 years.
Many elderly subjects are at risk of respiratory failure due to effect of age on their ventilatory system and the deterious effects of toxins \& respiratory diseases. ${ }^{(\mathbf{1 2})}$

These findings were agreed with that reported by John \& Jay, 2000 who found a significant reduction in FVC, $\mathrm{FEV}_{1}$ \& MVV with aging. ${ }^{(13)}$

So due to the changes in the chest wall \& lungs with aging; there is a progressive decrease in the vital capacity and an increase in the residual volume. ${ }^{(14)}$

The result of this study showed that: "group $\mathrm{A}$ " at the pre-exercise showed the mean of ventilatory functions as the following; FVC was $1.105 \mathrm{~L}, \mathrm{FEV}_{1}$ was $1.390 \mathrm{~L}$ and MVV was 43.410, while after 8 weeks they became $1.350 \mathrm{~L}, 1.613 \mathrm{~L} \& 49.964 \mathrm{~L}$ respectively with improved percentage of $22.20 \%, 16.06 \%$ \& $15.10 \%$ respectively.

The combination of incentive spirometer \& deep breathing exercise were used at 1996 by Hall et al., as a prophylaxis against respiratory deterioration after abdominal surgery. ${ }^{(15)}$

At the same point Kurabayashi, 1998 stated that the breathing exercises can improve ventilatory functions and blood gas exchange in patients over 80 years with chronic obstructive pulmonary disease. ${ }^{(\mathbf{1 6})}$

Weiner et al., 1999 concluded a significant increase in $\mathrm{FVC} \& \mathrm{FEV}_{1}$ by diaphragmatic breathing exercise. $^{(17)}$

The improvement of ventilatory functions after breathing exercise in elderly may result from correction in efficiency of abnormal breathing 
pattern and strengthening of diaphragm (George et al., 2000), or due to facilitation of deep breathing or enhancement of chest expansion according to Weiner et al., 1999. ${ }^{(\mathbf{1 8}, \mathbf{1 7})}$

The current results were supported by George et al., 2000 who stated that diaphragmatic breathing exercise is a maneuver to increase tidal volume \& ventilatory functions. ${ }^{(18)}$

The results of ventilatory functions showed significant improvement after the study program that agree with outcome of the research findings of Mahmoud et al., 2002 who experienced a significant improvement in ventilatory function tests after six weeks of physical training in the form of diaphragmatic breathing exercise, incentive spirometer, gait training \& upper limb exercise associated with respiration. ${ }^{(6)}$

While for "group B" the preexercise showed the mean of ventilatory functions as the following; FVC was $1.103 \mathrm{~L}, \mathrm{FEV}_{1}$ was $1.357 \mathrm{~L}$ and MVV was 43.967, while after 8 weeks they became $1.469 \mathrm{~L}, 1.646 \mathrm{~L}$ \& 54.475 L respectively with highly significant improved percentage of $33.12 \%, \quad 21.27 \% \quad \& \quad 23.90 \%$ respectively.

A significant increase in $\mathrm{FEV}_{1}$ \& MVV in elderly subjects was observed. This could be due to strengthening of respiratory muscles and improvement in elastic properties of the lungs \& chest incidental to regular practice of forced breathing, similar ventilatory training even in subjects with chronic obstructive pulmonary diseases have been shown to improve these ventilatory functions of the lungs. ${ }^{(19)}$
Merk, 2001 mentioned that MVV is important because it reflects the severity of airway obstruction as well as the patient's respiratory reserves, muscle strength $\&$ motivation. ${ }^{(20)}$

The current results were supported by Mckeough (B) et al., 2003 who stated that when the arms are elevated above $90^{\circ}$, some muscles as Pectoralis will expand the rib cage by passive stretching, where as others, such as Serratus anterior will do so by active contraction. ${ }^{\text {(21) }}$

Plekonen et al., 2003 claimed that improvement of maximum voluntary ventilation may be referred to increase in inspiratory \& expiratory muscles power and endurance capabilities as well as improved compliance of the lung-thorax system and so the ability of respiratory muscles to contract \& relax rapidly and deeply is enhanced. ${ }^{(22)}$

Concerning sex in relation to the ventilatory functions, there was no significant difference between female $\&$ male in both groups.

Also Iskander et al., 2003 who proved that there was no significant difference between female \& male in the results of pre- \& post- courses of exercise for $\mathrm{FVC}, \mathrm{FEV}_{1} \& \mathrm{MVV}$ when applying breathing exercises on elderly subjects. ${ }^{(23)}$

Abd Al-Aal et al., 2006 who proved that there was non significant correlation between sex \& percentage of improvement when the ventilatory function responses were studied to support the versus unsupported arm exercise among elderly. ${ }^{(24)}$

The results were inconsistent with Iskander et al., 2003 who proved that there was a significant difference in maximum voluntary ventilation in 
pre- \& post- course of breathing exercise towards males. ${ }^{(23)}$

Conclusion:

The result of the current study confirmed that diaphragmatic breathing exercise, incentive spirometer and chest mobilizing exercise produce significant and remarkable benefits on ventilatory functions, specially FVC \& MVV in elderly subjects.

Recommendation:

It was recommended by the physical therapist to follow the diaphragmatic breathing exercise, incentive spirometer and chest mobilizing exercise for the elderly subjects to improve the ventilatory functions.

\section{REFERENCE}

1- Arnel, M., and Sastry, G. P. (2001): Functional Decline in Aging and Disease. A role for Apoptosis. J. A. G. S., Vol. (49), pp: $1234-1240$.

2- Robergs, R. A., and Roberts, S.O. (2000): Exercise Physiology for Fitness, Performance and Health. $1^{\text {st }}$ ed., McGraw-Hill Education A division of the McGraw-Hill Company, Ch.18, pp: 56.

3- Polatti, M., Akyol, A., and Cildag, O. B. (2001): Pulmonary Function Tests in Parkinson's Disease. Eur. J. Neural., Vol. (8), pp: $341-345$.

4- Sanchez-Riera, Montemagor, R., Or Tega, R., Geljudo, R., Del Catillo and Castillo, G. (2001): Inspiratory Muscle Training in Patient with COPD.
Effect on Dyspnea, Exercise Performance and Quality of Life. Chest, Vol. 120 (3), pp: 748 756.

5- Carolyn Kisner, and Lunn Allen Colby (1996): Therapeutic Exercise. Foundation and Techniques. $3^{\text {rd }}$ ed., Ch, 19, F. A. Davis Company, Philadelphia, pp: $665-674$.

6- Mahmoud, M. M., Rahmy, A. F., Sultan, I. E., and Serri, Z. M. H. (2002): Efficacy of Physical Training on Ventilatory Function in Alzeheimer's. A master thesis, Faculty of Physical Therapy, Cairo University, pp: 42 -50 .

7- Schere, T.A., Spengler, C. M., Owassapain, D., Imbhaf E., and Boutellier, U. (2000): Respiratory Muscle Endurance Training in Chronic Obstructive Pulmonary Disease Impact on Exercise Capacity and Quality of Life. Am. J. Respir. Crit. Care Med., Vol. (162), pp: 1709 1714.

8- Aaron, S.D., Dales, R.E. and Cardinal, P. (1999): How Accurate is Spirometery at Predicting Restrictive Pulmonary Impairment? Chest. Mar, Vol. 115 (3), pp: $869-873$.

9- Balatopoulos, G., Fildisis, G., Mgrinthefs, P. (2000): Reference Values and Prediction Equations for FVC and FEV in the Greek Elderly. Lung, vol. 178 (4), pp: $201-212$.

10- Youn, S.M., Halen, V.,Robinson, D., R. (2001): Pulmonary Function Test. J. 
Appl. Physiol., Vol. (39), pp: $54-$ 59.

11- Ali, H. M., A. Hady, A.A., A. Kader, S. M., Mostafa, N. M. (2007): Effect of Laser Puncture on Ventilatory Function in Asthmatic Patients. A master thesis, Faculty of Physical Therapy, Cairo University, pp: 38.

12- Pfitznmeyer, P., and Camus, A. (1998): Reversible bronchial Spasm Syndrome in Elderly. May, Vol. 27 (18), pp: $878-883$.

13- John, F. M., and Jay, A. N. (2000): Textbook of Respiratory Medicine. $3^{\text {rd }}$ ed., W. B. Saunders Company, Ch. 28, pp: $857-860$.

14- Andrew, A. G. (2000): Geriatric Physical Therapy. $2^{\text {nd }}$ ed., Ch.14, Mosby, Philadelphia, pp: 226 229.

15- Hall, J. C., Tarala, R. A., and Hall, J. L. (1996): A Case Control Study of Post Operative Pulmonary Complications after Lap Aroscope. Journal of Laparoendox of Surgery, Vol. 6 (2), pp: $87-92$.

16- Kurabayashi, H.., Machida, I., and Kubota, K. (1998): Improvement in Affection Fraction of Hydrotherapy as Rehabilitation in patients with Chronic Pulmonary Emphysema. Physither. Res. In., Vol. 3 (4), pp: $284-291$.

17- Weiner, P., Waizmas, J., Magadle, R., Berar Yanay, and Pelled, B. (1999): The effect of scientific Inspiratory Muscle on the Sensation of Disease and Exercise Tolerance in Patients with Congestive Heart. Joulre Clin-Cardio. Vol.22(1), pp: 727 732.

18- George R., Light R., and Matthay M. (2000): Chest Medecine; Essentials of Pulmonary and Critically Care Medicine. $4^{\text {th }}$ ed., New York and London, Ch. 2, pp: 192 - 193.

19- Lacasse, Y. (1998): Is There Really A controversy surrounding the Effectiveness of Respiratory Rehabilitation in COPD? Chest, Vol. (114), pp: 1-4.

20- Merck, (2001): Pulmonary Disorders and Pulmonary Functions Testing, White House State in USA. The Merck Manual of Diagnosis and Therapy J., Vol. 20 (5), pp: $4-7$.

21- Mckeough, Z. J., Alison, J. A., and Bye, P. T. (B) (2003): Arm Positioning Alerts Lung Volumes in Subjects with COPD and Healthy Subjects. Aust. J. Physiother., Vol. 49 (2), pp: 133 $-137$.

22- Pelkonen, M., Notkola, I. L., Lakka, T., Tukianinen, H. O., Kivinen, P., and Nissinen (2003): Delaying Decline in Pulmonary Function with Physical Activity. Am. J. Respir. Crit. Care Med., Vol. (168), pp: 494 - 499.

23- Iskander, M. A., Salem, N. M., El-Bouhy, S. M., and Ismael, A. F. (2003): Efficacy of Different Methods of Breathing Exercise on Ventilatory Function in Elderly. A master thesis, Faculty of Physical Therapy, Cairo University, pp: 5, $112-115$. 
24- Abd Al-Aal, M. E., Hamed, H.

M., Rahmy, A. F. and Mahamed, N. H. (2006): Ventilatory Function Response to Supported versus Unsupported
Arm Exercise among Elderly. A master thesis, Faculty of Physical Therapy, Cairo University, pp: 91.

\section{دراسة استجابة وظائف التنفس لتمرينات التنفس مقارنة بتمرينات التنفس و تحريك الصدر في كبار السن السن مقن

\author{
محد /بر/هيم - بينى كامل محمد* - عطا أكرم /ببر/هيم

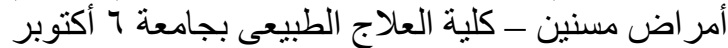 \\ * باطنة ـ كلية الطب البشرى بجامعة 7 أكتوبر البر البر}

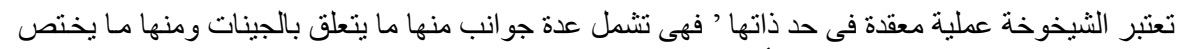

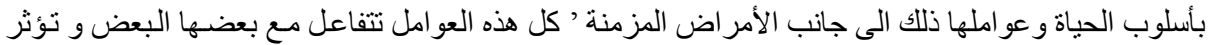

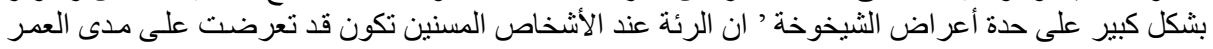

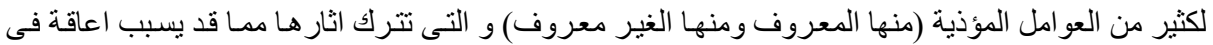

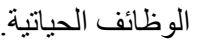

فلى هذه الدراسة • بـ شخص مسن تم عمل فحوصـات اكلينيكية لهم على الجهاز التنفسى ' القلب و الجهاز

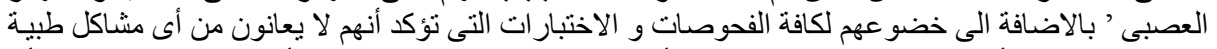

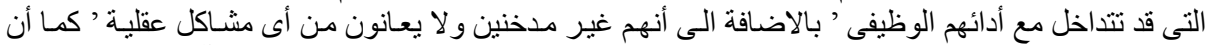

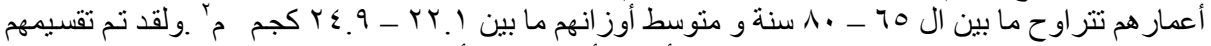

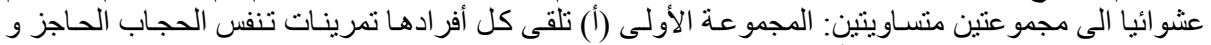

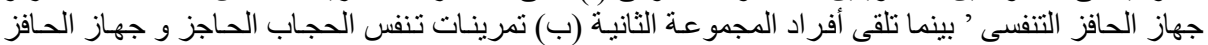

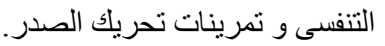

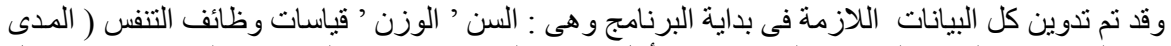

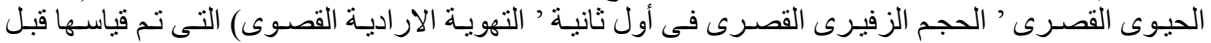

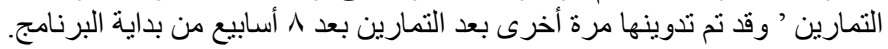

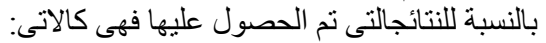

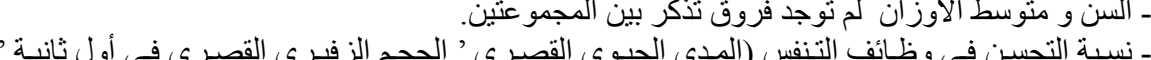

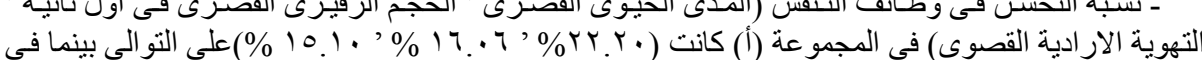

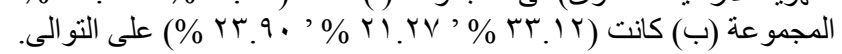

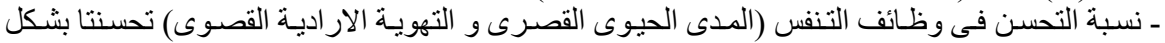

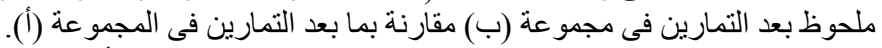

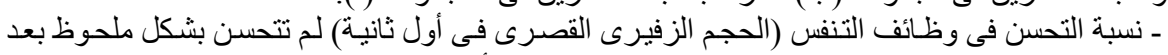

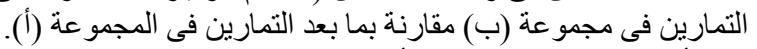

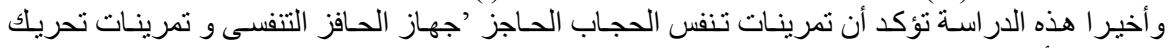

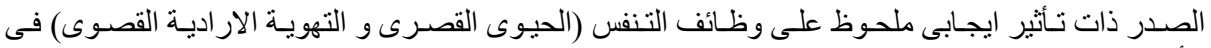

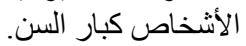

